\title{
Effect of slow release urea in sheep feed on nitrogen balance
}

\section{Ureia de liberação lenta na alimentação de ovinos sobre o balanço de nitrogênio}

\author{
Luiz Juliano Valério Geron ${ }^{1 *}$; Jocilaine Garcia ${ }^{1}$; Sílvia Cristina de Aguiar'; Fabiana \\ Gomes da Costa ${ }^{2}$; Ana Paula da Silva ${ }^{3}$; Eurico Lucas Sousa Neto ${ }^{4}$; Joilma Toniolo \\ Honório de Carvalho5; Lucas Silva Roberto ${ }^{5}$; Kallynka Samara Martins Coelho; \\ Ilda Souza Santos ${ }^{5}$
}

\begin{abstract}
The aim of this study was to evaluate the effect of inclusion of $0.0 \%, 0.4 \%, 0.8 \%$, and $1.2 \%$ slow release urea (SRU) in sheep feed on nitrogen balance (intake, fecal and urinary excretion, nitrogen absorbed and retained and/or nitrogen balance). Four sheep with an average body weight (BW) of $30.8 \pm 1.7 \mathrm{~kg}$ were distributed using a Latin square experimental design. Sheep were allocated in metabolic cages and received two meals a day. The data were subjected to analysis of variance and differences were tested using a regression equation with a $5 \%$ probability. The inclusion of $0.0 \%, 0.4 \%, 0.8 \%$, and $1.2 \%$ SRU in sheep diets did not change ( $p>0.05)$ nitrogen intake (NI), with an average value of $20.49 \mathrm{~g}$ animal day $^{-1}$ and $1.57 \mathrm{~g}\left(\mathrm{~kg}^{0.75}\right)^{-1}$. The inclusion of $0.0 \%, 0.4 \%, 0.8 \%$, and $1.2 \%$ SRU in sheep diets did not affect $(\mathrm{p}>$

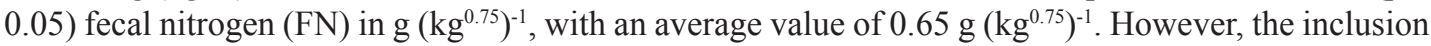
of SRU changed $(\mathrm{p}<0.05)$ the FN, expressed as g animal day ${ }^{-1}$, and $\% \mathrm{BW}$, in a quadratic manner. The lowest FN excretion was $7.63 \mathrm{~g}^{2}$ animal day ${ }^{-1}$ and $36.41 \% \mathrm{NI}$, and it was obtained at inclusion levels of $0.82 \%$ and $0.66 \%$ SRU, respectively. The inclusion of $0.0 \%, 0.4 \%, 0.8 \%$, and $1.2 \%$ SRU in sheep diets had a quadratic effect $(\mathrm{p}<0.05)$ in urinary nitrogen $(\mathrm{UN})$, expressed as $\mathrm{g}$ animal day ${ }^{-1}, \mathrm{~g}\left(\mathrm{~kg}^{0.75}\right)^{-}$ ${ }^{1}$, and $\%$ of NI. The minimum values calculated with the equations for UN were $0.86 \mathrm{~g}$ animal day ${ }^{-1}$,

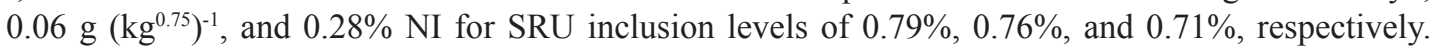
The inclusion of $0.0 \%, 0.4 \%, 0.8 \%$, and $1.2 \%$ SRU in sheep diets did not change $(\mathrm{p}>0.05)$ the NB expressed as $\mathrm{g}$ animal day ${ }^{-1}(10.86)$ and $\mathrm{g}\left(\mathrm{kg}^{0.75}\right)^{-1}(0.82)$. However, the NB expressed as \% NI or in relation to the NI responded in a quadratic manner $(p<0.05)$ to the inclusion of different levels of SRU in sheep food. The maximum value for NB was $59.68 \% \mathrm{NI}$ and it was obtained at $0.68 \%$ SRU. Thus, the inclusion of $0.6 \%$ to $0.8 \%$ slow release urea in sheep diets provides the lowest fecal and urinary nitrogen losses. In addition, these levels provide the best NB values, expressed as a percentage of NI.

Key words: Excretion. Faces. Intake. Non-protein nitrogen. Urine.
\end{abstract}

\section{Resumo}

Objetivou-se avaliar a inclusão de $0,0 \% ; 0,4 \% ; 0,8 \%$ e $1,2 \%$ de ureia de liberação lenta (ULL) na

1 Profs., Universidade do Estado de Mato Grosso, UNEMAT, Pontes e Lacerda, MT, Brasil. E-mail: 1jgeron@yahoo.com.br; scaguiar@unemat.br; euriconeto@unemat.br; jo@unemat.br; scaguiar@unemat.br

2 Prof ${ }^{\text {a }}$, Universidade Federal de Mato Grosso, UFMT, Cuiabá, MT, Brasil. E-mail: fabiana_gcosta@hotmail.com

3 Discente, Curso de Mestrado, Pós-Graduação em Zootecnia, Universidade Estadual de Mato Grosso do Sul, UEMS, Aquidauana, MS, Brasil. E-mail: anapaula2886@gmail.com

4 Prof., Universidade do Estado de Mato Grosso, UNEMAT, Pontes e Lacerda, MT, Brasil. E-mail: euriconeto@unemat.br

5 Discentes, Curso de Bacharelado em Zootecnia, UNEMAT, Pontes e Lacerda, MT, Brasil. E-mail: joilma_thc@hotmail.com; zooteclucas@hotmail.com; coelho-ksm@hotmail.com; ildasouza20@hotmail.com

* Author for correpondence 
alimentação de ovinos sobre o balanço de nitrogênio (consumo, excreção fecal e urinária de nitrogênio, nitrogênio absorvido e balanço de nitrogênio). Foram utilizados quatro ovinos com peso corporal (PC) médio de 30,8 $\pm 1,7 \mathrm{~kg}$, distribuídos em um delineamento em quadrado latino. Os ovinos foram alocados em gaiolas de metabolismo e receberam duas refeições por dia. Os dados do balanço de nitrogênio dos ovinos foram submetidos à análise de variância e as diferenças observadas para as variáveis estudadas foram testadas utilizando equação de regressão a $5 \%$ de probabilidade. A inclusão de $0,0 \% ; 0,4 \% ; 0,8 \%$ e $1,2 \%$ de ULL na alimentação dos ovinos não alterou $(\mathrm{p}>0,05)$ o consumo de nitrogênio $(\mathrm{N})$, com valor médio de 20,49 $\mathrm{g}$ animal dia ${ }^{-1}$ e 1,57 gramas por quilo de peso metabólico $\left(\mathrm{g} \mathrm{kg}^{0,75}\right)^{-1}$. A inclusão de níveis crescentes de ULL na alimentação de ovinos não influenciou $(p>0,05)$ o nitrogênio fecal (NF)

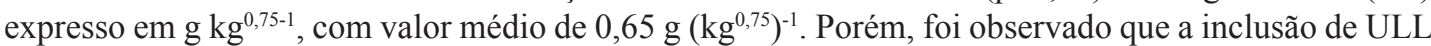
alterou $(\mathrm{p}<0,05)$ de maneira quadrática o NF expresso em $\mathrm{g}$ animal $\mathrm{dia}^{-1}$. O menor valor estimado de excreção do NF foi de 7,63 g animal dia ${ }^{-1}$ para o nível de inclusão da ULL de $0,82 \%$. A utilização dos níveis de $0,0 \% ; 0,4 \% ; 0,8 \%$ e $1,2 \%$ de ULL na alimentação dos ovinos propiciou um comportamento quadrático $(\mathrm{p}<0,05)$ para o $\mathrm{N}$ urinário $(\mathrm{NU})$ expresso em $\mathrm{g}$ animal dia ${ }^{-1} ; \mathrm{g}\left(\mathrm{kg}^{0,75}\right)^{-1} \mathrm{e} \%$ do $\mathrm{N}$ consumido (NC). Os pontos de mínimo obtidos pelas equações para o $\mathrm{NU}$ foram de $0,86 \mathrm{~g}$ animal dia $^{-1} ; 0,06 \mathrm{~g}$ $\left(\mathrm{kg}^{0,75}\right)^{-1}$ e $0,28 \% \mathrm{NC}$, para os teores de inclusão de $0,79 \% ; 0,76 \%$ e $0,71 \%$, respectivamente. A inclusão de $0,0 \% ; 0,4 \% ; 0,8 \%$ e $1,2 \%$ de ULL na alimentação de ovinos não alterou (p>0,05) o balanço de

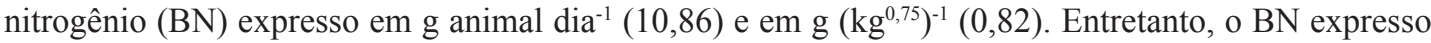
em \% NC ou em relação ao $\mathrm{NC}$ apresentou um comportamento quadrático $(\mathrm{p}<0,05)$ com a inclusão dos diferentes níveis de ULL nas rações de ovinos. O valor máximo do BN de 59,68\% NC foi obtido para o nível de $0,68 \%$ de ULL. Assim, a inclusão de $0,6 \%$ a $0,8 \%$ de ureia de liberação lenta na alimentação de ovinos propicia as menores perdas do nitrogênio fecal e urinário, além de proporcionar os melhores valores de balaço de nitrogênio expresso em percentagem do nitrogênio consumido.

Palavras-chave: Consumo. Excreção. Fezes. Nitrogênio não proteico. Urina.

\section{Introduction}

Urea contains on average $42-46.7 \%$ nitrogen $(\mathrm{N})$, which is equivalent to $262-292 \%$ crude protein (CP), and consists entirely of non-protein nitrogen (NPN) (PINOS-RODRIGUEZ et al., 2010). Specific characteristics of urea include mineral deficiency, lack of energy value, and being extremely soluble in water (SILVEIRA et al., 2013).

In the rumen, urea is hydrolyzed into ammoniacal nitrogen $\left(\mathrm{N}-\mathrm{NH}_{3}\right)$, which is later incorporated by ruminal microorganisms and transformed into amino acids and proteins of great importance to ruminants. The complex environment of the rumen, populated by different species of microorganisms, each with its own particularities in terms of nutrient requirements and metabolism, allows this process to occur (SANTOS; PEDROSO, 2011).

Any excess of ammonia is absorbed by the rumen wall and can become toxic to the animal, because the liver is unable to metabolize it. Furthermore, the metabolism of ammonia into urea involves energy expenditure (BOURG et al., 2012). Circulating urea can be recycled and returned to the rumen, via the rumen wall and saliva, or it can be excreted through urine (OWENS; ZINN, 1993).

According to Mendes (2009), if the quantity of carbohydrates fermented in the rumen exceeds the protein degradation rate, microbial growth and efficiency of the digestive process are negatively affected.

According to Clark et al. (1992), a reduced amount of available nitrogen in the rumen results in an incomplete fermentation, caused by lower ruminal fermentation, with the microorganisms, deficient in nitrogen, diverting ATP to the accumulation of carbohydrates instead of using it for microbial protein synthesis. Conversely, an excessive intake of protein without adequate amounts of energy results in loss of nitrogen in the excreta (MENDES, 2009; RUSSEL et al., 1992). In contrast, when there is an adequate energy supply, the microorganisms correctly use $\mathrm{N}_{-} \mathrm{NH}_{3}$ in the 
ruminal environment. Therefore, both protein and energy sources must be provided so they can be degraded in synchrony; otherwise, in addition to $\mathrm{N}-\mathrm{NH}_{3}$ losses due to excessive release, microbial production will be reduced and food degradation will decrease (ZEOULA et al., 2006).

According to Castaneda et al. (2009), the fact that the rate of release of $\mathrm{N}-\mathrm{NH}_{3}$ must coincide with the rate of digestion of carbohydrates, has led the industry to seek the development of compounds with a slow release of NPN, which have less risk of poisoning animals (PIRES et al., 2004). For instance, the use of slow release urea (SRU) allows a better utilization of $\mathrm{N}$ and reduces the risk of animal poisoning (SOUZA et al., 2010; GALLO et al., 2015).

The literature reports different results on the use of SRU in the nutrition of sheep and other ruminants. According to Lizarazo et al. (2014), the use of protected urea does not affect the digestibility of dry matter (DM) and dietary neutral detergent fiber (NDF), or microbial synthesis in lambs.

Similarly, Gallo et al. (2006), when evaluating the use of common (livestock) and protected urea (SRU) in sheep feed, observed that the use of livestock or encapsulated urea in Dorper and Texel crossbred lambs did not influence the performance and carcass parameters.

However, a study by Alves et al. (2012), evaluating the effect of urea levels in sheep feed on nitrogen balance (NB), plasma urea-N, and ruminal parameters, showed that the inclusion of urea up to a level of $1.5 \%$ of the dietary DM linearly increased the concentrations of $\mathrm{N}^{-\mathrm{NH}_{3}}$ in ruminal fluid and urea-N in plasma; however, it did not alter the NB.

A study conducted by Azevedo et al. (2015) to evaluate the use of SRU in place of soybean meal (SM) in finishing confined cattle, showed that there were no differences in the rumen parameters of the animals that received the diet containing protected urea.
According to a study by Alves et al. (2014), the substitution of conventional urea by SRU $\left(\right.$ Optigen ${ }^{\circledR}$ ) in sheep feed altered the nitrogen intake (NI) and the plasma urea-N concentration, but no the excretion of urinary nitrogen (UN).

According to Broderick et al. (2009), SRU supplementation in diets of ruminants fed with high levels of easily fermentable carbohydrates can improve the utilization of dietary nitrogen and, consequently, the microbial protein synthesis in the rumen.

A study conducted by Geron et al. (2016) evaluated the inclusion of $0.0 \%, 0.4 \%, 0.8 \%$, and $1.2 \%$ SRU in sheep feed on intake and digestibility of nutrients and ruminal parameters. It showed that inclusion of SRU did not alter nutrient intake and ruminal parameters; however, it caused a change in the digestibility coefficient of DM and CP. Moreover, the $\mathrm{N}_{-} \mathrm{NH}_{3}$ concentration in the rumen fluid of sheep fed diets containing different levels of SRU was influenced by the time elapsed since the last feeding.

In general, the proper use of NPN and true protein during the ruminal fermentation process contributes to the total amount of microbial protein flowing into the small intestine (GARDINAL, 2012). In addition, synchronization of substrates (energetic and protein foods) is required to maximize the efficiency of microbial synthesis and the equilibrium of the fermentation parameters and, consequently, to improve the digestion of nutrients and the animal performance (DEWHURST et al., 2000). Thus, several factors affect the extent of $\mathrm{CP}$ degradation in the rumen, such as the physical and chemical composition of $\mathrm{CP}$, i.e., the ratio of rumen degradable protein (RDP) and rumen nondegradable protein (RNDP) (SANTOS; PEDROSO, 2011). In addition, CP degradation is affected by the proportion of roughage to concentrate and, consequently, by the synchronization of the protein and carbohydrate sources present in the total feed (ZEOULA et al., 2006). Therefore, the use of SRU in 
sheep diets containing $65 \%$ roughage (corn silage) and $35 \%$ concentrate (milled corn grain [MG] and SM) may provide a suitable nitrogen balance for the animals.

Consequently, NB is an important tool to determine the efficiency of $\mathrm{N}$ utilization and the $\mathrm{N}$ losses in ruminants. According to Geron et al. (2015a), NB is the $\mathrm{N}$ retained, obtained by subtracting the $\mathrm{N}$ quantities excreted via feces and urine from the amount of $\mathrm{N}$ ingested. In addition, $\mathrm{NB}$ is indicative of protein metabolism, and is used to evaluate if the nitrogenous compounds of the animal are in equilibrium, avoiding productive, reproductive, and environmental damage due to the supply of excessive amounts of protein and the lack of synchrony in the degradation of energy and protein in the rumen (AMORIM, 2013).

Therefore, the aim of this study was to evaluate the effect of $0.0 \%, 0.4 \%, 0.8 \%$, and $1.2 \%$ SRU in the diet of sheep on the intake and urinary and fecal excretion of nitrogen, nitrogen uptake, and NB.

\section{Material and Methods}

The study was conducted at the University of the State of Mato Grosso (UNEMAT), University Campus of Pontes and Lacerda, in the Animal Metabolism Sector (SeMA) and Laboratory of Food Analysis and Animal Nutrition (LAANA) belonging to UNEMAT, located at $15^{\circ} 19^{\prime} 05^{\prime \prime}$ south latitude and $59^{\circ} 13^{\prime} 26^{\prime \prime}$ west longitude, and at an altitude of $295 \mathrm{~m}$, protocol 006/2016 CEUA.

Four uncastrated, approximately 8-month-old male sheep, undefined breed (UDB) with a mean body weight (BW) of $30.8 \pm 1.7 \mathrm{~kg}$ were used in this study. They were housed in metabolic cages containing individual feeders and drinkers.

The sheep were dewormed with an ivermectinbased product (Ivomec ${ }^{\circledR}$ injectable Merial, with a concentration of $1 \mathrm{~g}$ of ivermectin per $100 \mathrm{ml}$ of vehicle), using $1 \mathrm{ml}$ of the vermifuge for each $50 \mathrm{~kg}$ of BW, 15 days before the beginning of the experimental period.

The animals were distributed using a $4 \times 4$ Latin square experimental design to evaluate the effect of SRU in sheep feed on intake, urinary and fecal excretion of nitrogen, as well as on nitrogen uptake and NB.

The SRU was purchased from a local industry in the city of Pontes and Lacerda, State of Mato Grosso, under the commercial name of Optigen Allthec ${ }^{\circledR}$ (NPN compound coated with biodegradable material). The levels of SRU tested were $0.0 \%$, $0.4 \%, 0.8 \%$, and $1.2 \%$ in DM. The maximum SRU level tested represents a $57 \%$ replacement of the nitrogen from SM by the NPN present in SRU.

The experimental diets were prepared using MG, SM, and SRU $\left(\right.$ Optigen $^{\circledR}$ ) as concentrated feed, and corn silage as roughage (Table 1). The diets were balanced to contain $14.0 \% \mathrm{CP}$ and $69.5 \%$ of total digestible nutrients (TDN) according to the NRC (2007) (Table 2), besides presenting a 65:35 roughage: concentrate ratio.

The experimental diets were provided ad libitum in two meals per day, at $06: 00$ and 18:00, so that there were approximately $10 \%$ leftovers, daily. Monitoring of leftovers was performed daily, before the first treatment of the day.

Corn silage, concentrated feed, and mineral salt were mixed at the time of feeding per animal/ day. Thus, $10 \mathrm{~g}$ of mineral mixture per sheep was provided daily, added directly to the total feed (roughage and concentrate) at the time of delivery, i.e., twice daily ( $5 \mathrm{~g}$ of salt meal per animal). The detailed chemical composition of the mineral salt was $120 \mathrm{~g} \mathrm{Ca} \mathrm{kg}^{-1}, 85 \mathrm{~g} \mathrm{P} \mathrm{kg}^{-1}, 16 \mathrm{~g} \mathrm{~S} \mathrm{~kg}^{-1}, 148 \mathrm{~g} \mathrm{Na}$ $\mathrm{kg}^{-1}, 50 \mathrm{mg} \mathrm{Co} \mathrm{kg}{ }^{-1}, 500 \mathrm{mg} \mathrm{Cu} \mathrm{kg}{ }^{-1}, 16 \mathrm{mg} \mathrm{Se} \mathrm{kg}{ }^{-1}$, and $4800 \mathrm{mg} \mathrm{Zn} \mathrm{kg}^{-1}$. 
Table 1. Bromatological composition of experimental feed.

\begin{tabular}{|c|c|c|c|c|}
\hline \multirow[t]{2}{*}{ Variables } & \multicolumn{4}{|c|}{ Experimental feed expressed in \% of DM } \\
\hline & $\mathrm{CS}^{1}$ & $\mathrm{GC}^{2}$ & $\mathrm{SM}^{3}$ & $\mathrm{SRU}^{4}$ \\
\hline Dry matter $\%$ & 28.40 & 91.68 & 90.35 & 100.00 \\
\hline Organic matter $\%$ & 92.16 & 97.22 & 93.37 & 99.00 \\
\hline Crude protein \% & 8.25 & 9.83 & 47.55 & 282.00 \\
\hline Degradable protein in the rumen ${ }^{6} \%$ & 6.03 & 4.05 & 30.17 & 282.00 \\
\hline Non-degradable protein in the rumen ${ }^{6} \%$ & 2.85 & 5.17 & 18.52 & -5 \\
\hline Ether extract \% & 1.61 & 4.34 & 1.51 & -5 \\
\hline Neutral detergent fiber $\%$ & 68.58 & 13.63 & 17.80 & -5 \\
\hline Acid detergent fiber $\%$ & 41.03 & 11.31 & 16.66 & -5 \\
\hline Crude fiber \% & 32.82 & 9.05 & 13.33 & -5 \\
\hline Non-nitrogen extract $\%$ & 52.53 & 74.00 & 31.23 & -5 \\
\hline Total carbohydrates $\%$ & 82.30 & 83.05 & 44.31 & -5 \\
\hline Non-fibrous carbohydrates \% & 13.72 & 69.42 & 26.51 & -5 \\
\hline Mineral matter $\%$ & 4.79 & 2.78 & 6.38 & -5 \\
\hline Total digestible nutrients ${ }^{6} \%$ & 62.30 & 86.03 & 80.73 & -5 \\
\hline
\end{tabular}

${ }^{1} \mathrm{CS}$ : corn silage; ${ }^{2} \mathrm{GC}$ : ground corn; ${ }^{3} \mathrm{SM}$ : soybean meal; ${ }^{4} \mathrm{SRU}$ : slow release urea; ${ }^{5}$ trace nutrient in the experimental feed; ${ }^{6} \mathrm{values}$ estimated according to Valadares Filho et al. (2010).

Table 2. Percentage and bromatological composition of experimental feed containing different levels of slow release urea (SRU).

\begin{tabular}{lcccc}
\hline Feed & \multicolumn{3}{c}{ Levels of slow release urea in experimental feed (\%) } \\
\cline { 2 - 4 } & 0.0 & 0.4 & 0.8 & 1.2 \\
\hline Corn Silage & 65.00 & 65.00 & 65.00 & 65.00 \\
Ground corn & 22.00 & 24.10 & 26.10 & 28.30 \\
Soy meal & 13.00 & 10.50 & 8.10 & 5.50 \\
Slow release urea & 0.00 & 0.40 & 0.80 & 1.20 \\
\cline { 2 - 4 } Total & 100.00 & 100.00 & 100.00 & 100.00 \\
\hline Composition expressed in \% of DM & & & & \\
Dry matter & 50.38 & 50.44 & 50.51 & 50.57 \\
Organic matter & 93.43 & 93.53 & 93.63 & 93.74 \\
Crude protein & 13.71 & 13.85 & 14.04 & 14.14 \\
Rumen degradable protein & 8.73 & 9.19 & 9.68 & 10.11 \\
Non-degradable protein in rumen & 5.40 & 5.04 & 4.70 & 4.33 \\
Ether extract & 2.20 & 2.25 & 2.30 & 2.36 \\
Neutral detergent fiber & 49.89 & 49.73 & 49.58 & 49.41 \\
Acid detergent fiber & 31.32 & 31.14 & 30.97 & 30.79 \\
Crude fiber & 25.06 & 24.92 & 24.78 & 24.63 \\
Total carbohydrate & 77.53 & 78.16 & 78.76 & 79.44 \\
& & &
\end{tabular}


continuation

\begin{tabular}{lcccc} 
Non-fibrous carbohydrates & 27.64 & 28.43 & 29.18 & 30.02 \\
Mineral matter & 4.55 & 4.45 & 4.36 & 4.25 \\
Total digestible nutrients $^{1}$ & 69.92 & 69.70 & 69.49 & 69.28 \\
\hline
\end{tabular}

${ }^{1} \mathrm{TDN}$ : total digestible nutrients calculated using the values in Table 1 and the proportions of each food item in Table 2.

The experiment lasted 84 days, divided into four experimental periods with a duration of 21 days each, with 15 days for adaptation of the sheep and 5 days for collection of leftover samples, urine, and feces, and the last day was used for collection of ruminal fluid as describe by Geron et al. (2015b).

Samples of corn silage were collected before delivery of the first meal of the day, during the collection period, to determine the DM content. During the experiment, leftover samples were collected for each animal in each experimental period.

For the collection of total feces, a nappa leather bag was adapted to each sheep during the experimental period. The feces from each animal were weighed daily in the morning and homogenized, and composite samples, corresponding to $10 \%$ of its total weight were taken (GERON et al., 2015a). The samples were placed in plastic bags that were identified with the animal and experimental period and stored in a freezer at $-10{ }^{\circ} \mathrm{C}$ for later analysis of fecal nitrogen (FN) content.

For total urine collection, plastic buckets covered with screens to prevent contamination with hairs, feed, and feces were placed under the metabolic cages during the collection period (five days). Hydrochloric acid ( $\mathrm{HCl})(20 \mathrm{~mL}, 1: 1)$ was added to each bucket to avoid volatilization of $\mathrm{N}$ as well as any possible fermentation (GERON et al., 2013). Urine collection was performed daily, always at the same time, i.e., in the morning before the 6:00 a.m. meal. Samples of $10 \%$ of the total urine collected during the day were placed in a single glass bottle, duly identified per animal and experimental period.
After the experimental collection period, samples of food leftovers and feces were dried in an oven at $55^{\circ} \mathrm{C}$ for 72 hours, processed in a knife mill using 1 $\mathrm{mm}$ sieves, and subsequently homogenized in equal quantities, based on dry weight, to form composite samples of feces and leftovers per animal per period per experimental diet ${ }^{-1}$.

The analyses of DM, organic matter (OM), CP, and ether extract (EE) in samples of food leftovers and feces were performed according to the AOAC (1990).

The determination of NDF of food leftovers and feces was performed according to Van Soest et al. (1991), without the use of sulfite and without correcting the NDF values with respect to the content of mineral matter of fiber. The acid detergent fiber (ADF) was determined according to the AOAC method (1990).

The determination of total carbohydrates $(\mathrm{TCH})$ of food leftovers and feces was obtained by the equation: $\mathrm{TCH}=\mathrm{OM}-[\mathrm{EE}+\mathrm{CP}]$ (SNIFFEN et al., 1992). The value of TDN of the experimental feed was estimated using the values of TDN shown in Table 1 according to Valadares Filho et al. (2010).

The content of non-fibrous carbohydrate (NFC) of food leftovers and feces was determined by the equation: $\mathrm{NFC}=100-[(\mathrm{MM}+\mathrm{NDF}+\mathrm{EE}+(\mathrm{CP}$ - CP urea + level of urea)] according to Sniffen et al. (1992). Determination of the $N$ content of urine was done by the semi-micro Kjeldahl method, using 6.25 as the conversion factor for $\mathrm{CP}$ according to the references from Silva and Queiroz (2002).

The content of $\mathrm{N}$ in the urine was calculated by the Kjeldahl method, described by Silva and 
Queiroz (2002), and the NB or N retained was obtained using the following formula: $\mathrm{NB}(\mathrm{g})=$ [( $\mathrm{N}$ supplied - $\mathrm{N}$ of leftovers) - ( $\mathrm{N}$ in feces $+\mathrm{N}$ in urine)] as described by Geron et al. (2015a). The N absorbed was calculated by the following equation: $\mathrm{N}$ absorbed $(\mathrm{g})=[(\mathrm{N}$ supplied $-\mathrm{N}$ of leftovers $)$ ( $\mathrm{N}$ in feces)] and the NI by the equation: $\mathrm{NI}(\mathrm{g})=$ [( $\mathrm{N}$ supplied - $\mathrm{N}$ of the leftovers)], as suggested by Moreno et al. (2010).

The variables studied were subjected to analysis of variance with the software Statistical Analysis and Genetics (SAEG) (UFV, 2007). When significant effects of the SRU inclusion levels $(0.0 \%, 0.4 \%, 0.8 \%$, and $1.2 \%)$ in feed on the variables (intake, urinary and fecal excretion of nitrogen, nitrogen absorption and nitrogen balance) were observed, regression analysis was performed at $5 \%$ significance.

\section{Results and Discussion}

The inclusion of $0.0 \%, 0.4 \%, 0.8 \%$, and $1.2 \%$
SRU in sheep feed did not change $(\mathrm{p}>0.05)$ the NI expressed as $\mathrm{g}$ animal day ${ }^{-1}$ and $\mathrm{g}\left(\mathrm{kg}^{0.75}\right)^{-1}$ (Table 3$)$, with mean values of $20.49 \mathrm{~g}^{2}$ animal day ${ }^{-1}$ and 1.57 $\mathrm{g}\left(\mathrm{kg}^{0.75}\right)^{-1}$ (Table 3). It is likely that the levels of DM, CP, and TDN, similar among the experimental diets (Table 2), influenced the results of NI. This indicates that the slower rate of disappearance of the $\mathrm{N}$ present in SRU resulted in a reduced change in the ruminal environment and had a low impact on the positive association effect, which could improve the intake of $\mathrm{N}$ and $\mathrm{DM}$ from the experimental feed. The inclusion of SRU in the feed of ruminants containing fast-fermenting carbohydrates can improve the synthesis of microbial protein (BRODERICK et al., 2009), because of the synchronization of energy and protein sources, consequently improving the fermentation environment (GALO et al., 2003), DM intake, and nutrient digestion. Another fact that corroborates the data obtained for the NI is the $\mathrm{CP}$ intake of the sheep fed with $0.0 \%, 0.4 \%, 0.8 \%$, and $1.2 \%$ SRU (GERON et al., 2016), which presented an average intake of $127.97 \mathrm{~g} \mathrm{CP}$ animal day $^{-1}$.

Table 3. Values of intake, fecal excretion of nitrogen, nitrogen balance, nitrogen absorbed ( $\mathrm{g}$ animal day $\left.{ }^{-1}\right)$ and nitrogen $^{-}$ balance with nitrogen absorbed for lambs fed with different levels of slow release urea (SRU).

\begin{tabular}{|c|c|c|c|c|c|c|}
\hline \multirow{2}{*}{ Variables } & \multicolumn{4}{|c|}{ Levels of slow release urea in experimental feed (\%) } & \multirow{2}{*}{ Regression } & \multirow{2}{*}{$\% \mathrm{CV}$} \\
\hline & 0.0 & 0.4 & 0.8 & 1.2 & & \\
\hline NI g animal day ${ }^{-1}$ & 20.66 & 21.16 & 21.52 & 18.56 & $Y=20.49$ & 13.00 \\
\hline NI $g\left(\mathrm{~kg}^{0.75}\right)^{-1}$ & 1.59 & 1.60 & 1.63 & 1.44 & $\mathrm{Y}=1.57$ & 14.02 \\
\hline $\mathrm{FN} \mathrm{g}\left(\mathrm{kg}^{0.75}\right)^{-1}$ & 0.75 & 0.65 & 0.56 & 0.64 & $Y=0.65$ & 13.39 \\
\hline NB g animal day ${ }^{-1}$ & 9.25 & 11.23 & 13.75 & 9.22 & $Y=10.86$ & 24.90 \\
\hline NB $g\left(\mathrm{~kg}^{0.75}\right)^{-1}$ & 0.70 & 0.87 & 1.01 & 0.71 & $\mathrm{Y}=0.82$ & 22.24 \\
\hline NA $g$ animal day ${ }^{-1}$ & 10.86 & 12.56 & 14.22 & 10.34 & $\mathrm{Y}=12.00$ & 20.18 \\
\hline NA $g\left(\mathrm{~kg}^{0.75}\right)^{-1}$ & 0.83 & 0.95 & 1.07 & 0.80 & $\mathrm{Y}=0.91$ & 20.41 \\
\hline $\mathrm{NB} \mathrm{NA}^{-1}$ & 0.85 & 0.92 & 0.95 & 0.90 & $\mathrm{Y}=0.90$ & 6.08 \\
\hline
\end{tabular}

NI: Nitrogen intake; $\mathrm{g}\left(\mathrm{kg}^{0.75}\right)^{-1}$ : grams per kilogram of metabolic weight; FN: Fecal nitrogen; NB: nitrogen balance; and NA: nitrogen absorbed. 
Some studies using SRU to replace the traditional sources of protein in the ruminant diet have been published (SOUZA et al., 2010; SANTOS et al., 2011; SANTINO, 2013). These studies have shown that substitution of traditional sources of true protein (soybean and cotton meal) by SRU does not alter the intake of DM and N. This response could be related to the release rate of traditional sources of protein, similar to that of SRU, which would lead to similar responses in DM and $\mathrm{N}$ intake when the true protein source (SM) is replaced by SRU.

A study conducted by Geron et al. (2015a) on NB in sheep fed with different levels of concentrates with an average CP value of $13.0 \%$, demonstrated that the concentrate levels had a quadratic effect on NI with a maximum NI of $12.62 \mathrm{~g}$ animal day ${ }^{-1}$

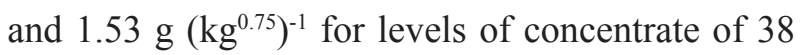

and $40 \%$, respectively. It should be noted that in the present study the roughage: concentrate ratio was $65: 35$, close to the recommended in the literature to obtain a maximum NI, when taking into account the proportion of fibrous carbohydrates and of easy ruminal fermentation.

The inclusion of $0.0 \%, 0.4 \%, 0.8 \%$, and $1.2 \%$ SRU in sheep feed did not influence $(\mathrm{p}>0.05)$ the $\mathrm{FN}$, which had an average value of $0.65 \mathrm{~g}\left(\mathrm{~kg}^{0.75}\right)^{-1}$ (Table 3). However, the inclusion of SRU changed $(\mathrm{p}<0.05)$ in a quadratic way the FN expressed as $\mathrm{g}$ animal day ${ }^{-1}$ and as $\% \mathrm{BW}$, as shown by the equations in Figures 1A and 1B. The lowest excretion of FN was $7.63 \mathrm{~g} \mathrm{day}^{-1}$ and $36.41 \%$ NI (nitrogen intake), for the levels of inclusion of SRU of 0.82 and $0.66 \%$, respectively, which were calculated with the regression equation shown in Figures $1 \mathrm{~A}$ and $1 \mathrm{~B}$.

Figure 1. Fecal nitrogen (FN) expressed as g animal day ${ }^{-1}(\mathrm{~A})$ and as percentage of nitrogen intake (\% NI) (B) of sheep fed diets containing different levels of slow release urea (SRU).

A

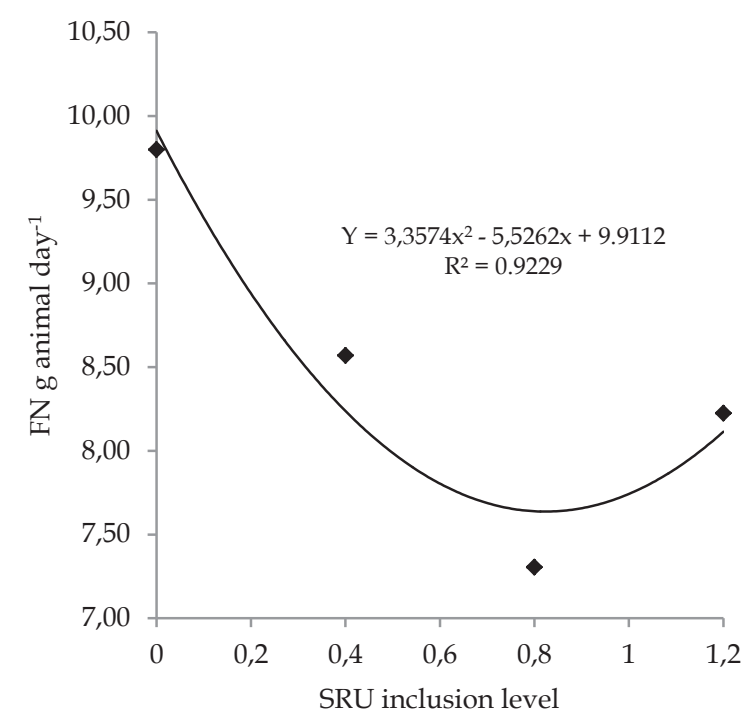

According to Kozloski (2002), Moreno et al. (2010), and Geron et al. (2015a), part of the reduction in the FN levels can be due to a reduction in the inflow of fermentative carbohydrates to the large intestine, which reduces microbial synthesis in this location and, consequently, causes a lower excretion
B

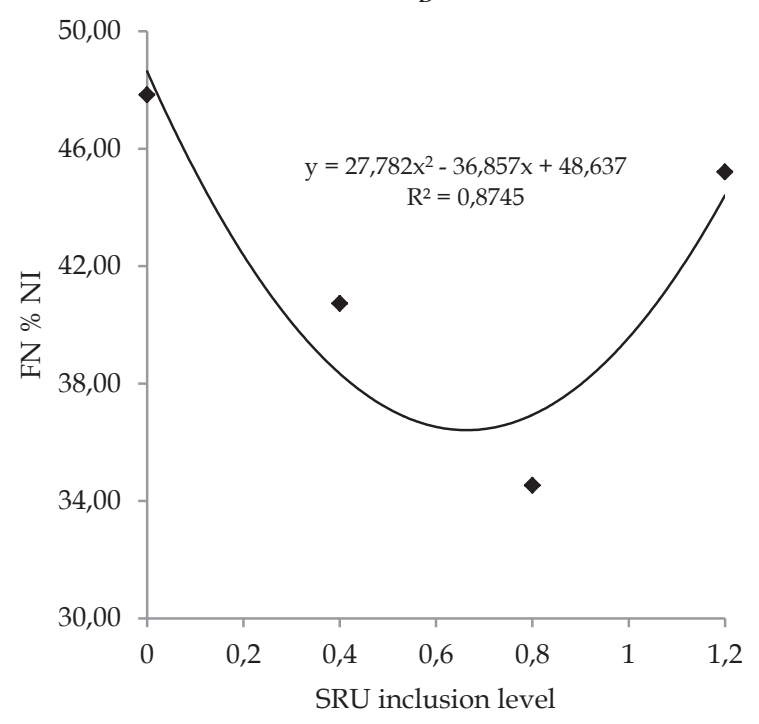

of microbial protein and total nitrogen. This was observed by Geron et al. (2016), who found that inclusion of $0.0 \%, 0.4 \%, 0.8 \%$, and $1.2 \%$ SRU in sheep feed had a quadratic effect on the coefficients of digestibility of $\mathrm{DM}$ and $\mathrm{CP}$, consequently reducing the amount of fermentable substrate that 
reached the small intestine. In addition, the same authors observed average values for DM and CP intake of $927.80 \mathrm{~g}$ animal day ${ }^{-1}$ and $127.97 \mathrm{~g}$ animal day $^{-1}$, respectively.

$\mathrm{UN}$, expressed as $\mathrm{g}$ animal day ${ }^{-1}, \mathrm{~g}\left(\mathrm{~kg}^{0.75}\right)^{-1}$, and $\%$ of NI, had a quadratic behavior $(\mathrm{p}<0.05)$ dependent on the level of inclusion of SRU in sheep feed as shown in Figure 2. The minimum points obtained by the equations (Figures 2A, 2B, and 2C)

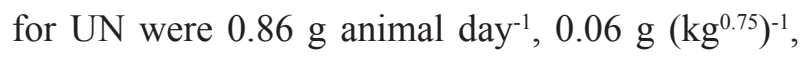
and $0.28 \%$ NI, for SRU levels of $0.79 \%, 0.76 \%$, and $0.71 \%$, respectively.

Approximately 50 to $70 \%$ of the nitrogenous compounds that reach the rumen are degraded by microorganisms, releasing ammonia. During ruminal fermentation, when the pool of ammonia exceeds the level of utilization by ruminal microorganisms, it is absorbed, reaching the liver through the enterohepatic circulation, where it is transformed into urea, which, together with the urea produced in the liver from amino acid metabolism, constitutes the majority of the plasma urea (ALVES et al., 2012). If urea is in excess in the blood circulation only part of it is recycled, via the saliva and the rumen wall, and goes back to the rumen, whereas the rest is excreted in the urine, causing endogenous losses of nitrogen (KOZLOSKI, 2002; CARVALHO et al., 2010). This was shown by Geron et al. (2016) who, when evaluating the inclusion of SRU in sheep feed, observed a quadratic behavior with a point of maximum digestibility of $69.92 \%$ for DM and $63.55 \%$ for CP estimated for the levels of inclusion of $0.50 \%$ and $0.70 \%$ SRU. These data are in agreement with the data obtained indicating that SRU in sheep feed at a range of 0.70 to $0.80 \%$ provides the best utilization of $\mathrm{N}$ in relation to urinary and metabolic losses.

Figure 2. Urinary nitrogen (UN) expressed as $g$ animal day ${ }^{-1}(\mathrm{~A})$, as $\mathrm{g}\left(\mathrm{kg}^{0.75}\right)^{-1}(\mathrm{~B})$, and as percentage of nitrogen intake (\% NI) (C) of sheep fed diets containing different levels of slow release urea (SRU).
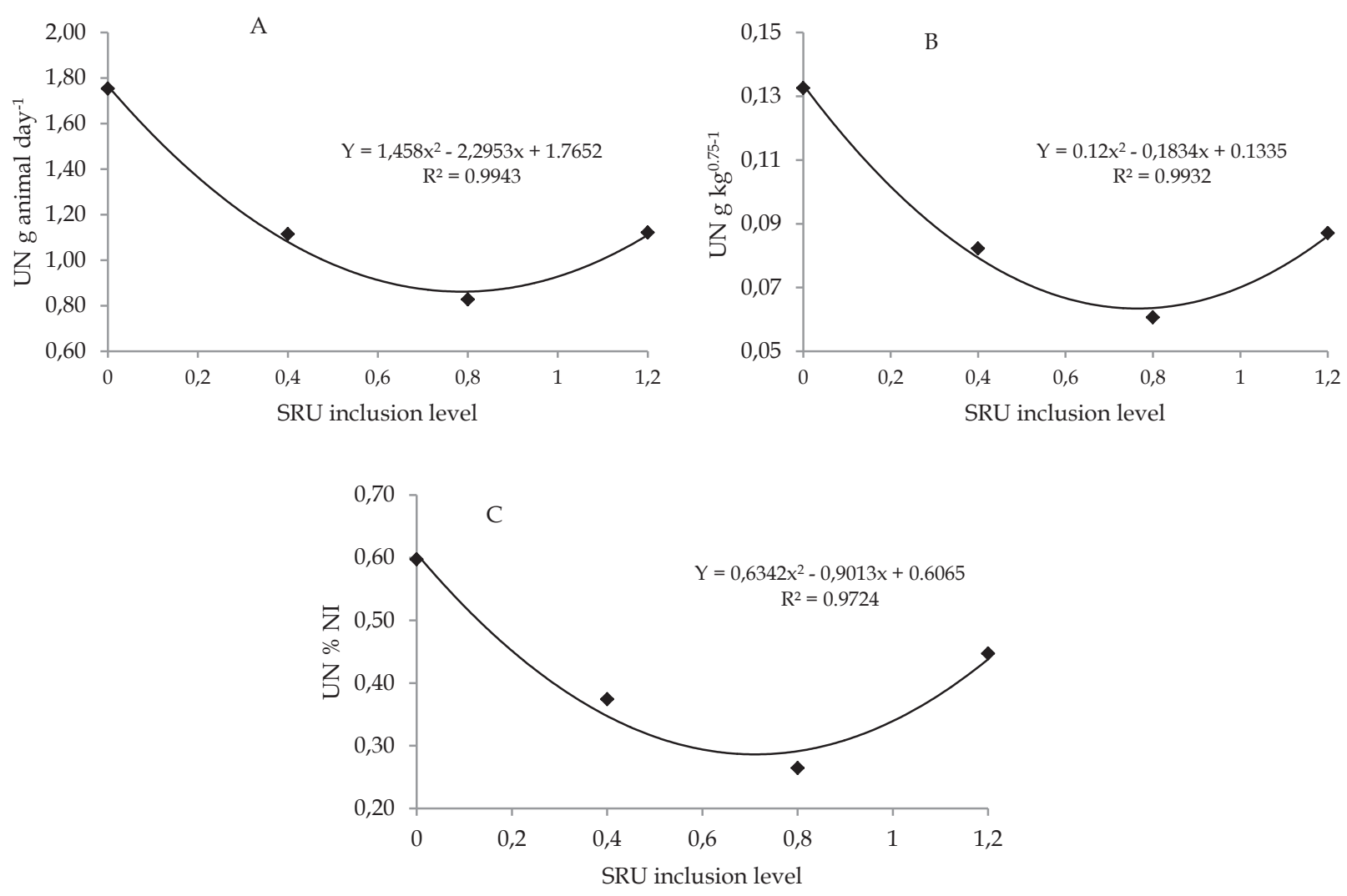
Nevertheless, the amount of UN is related to the content of CP in the diet, with increased excretion of urea via the urine when NI increases, as this results in higher production of urea in the liver, whereas a low NI leads to a decrease in the excretion of urea via the urine to maintain the plasma urea pool, under homeostatic physiological control (ZEOULA et al., 2006). However, Geron et al. (2016) demonstrated that the inclusion of up to $1.2 \%$ SRU in sheep feed does not alter the intake of DM and CP in feeds with a CP content of $13.5 \%$. The quadratic effect observed in this study for the urinary excretion of $\mathrm{N}$ is probably related with an improvement in the ruminal fermentation environment as the concentration of $\mathrm{N}^{-\mathrm{NH}_{3}}$ in the ruminal fluid was around $19.01 \mathrm{mg}$ of $\mathrm{N}^{-N_{3}} 100 \mathrm{~mL}^{-1}$ for a feed containing up to $1.2 \%$ SRU (GERON et al., 2016).

The losses of $\mathrm{N}$ were higher by the fecal route than by the urinary route, with mean values of 7.63 and $0.86 \mathrm{~g}$ animal day ${ }^{-1}$, respectively. According to Furtado et al. (2014), the fecal excretion of $\mathrm{N}$ is not influenced by the levels of CP in the diet, but the $\mathrm{UN}$ increases linearly with the protein content in the diet. The feeds of the present study were isoproteic and contained $14 \% \mathrm{CP}$ as required by the NRC (2007) for this animal category; therefore, little loss of $\mathrm{N}$ likely occurred via urine.

A study conducted by Santos et al. (2012) to evaluate the NB in sheep fed diets based on forage palm and conventional urea, demonstrated that levels of $0.0 \%, 0.7 \%, 1.4 \%$, and $2.1 \%$ of conventional urea in the diet based on forage palm resulted in a linear increase $(p<0.05)$ in the UN. The variation in the value of UN observed by these authors was 5.7 to $12.6 \mathrm{~g}$ animal day $^{-1}$, respectively, for the levels of $0.0 \%$ to $2.1 \%$ of conventional urea in the diet. The authors observed that the increase in UN loss had a direct influence on nitrogen retention, which presented a quadratic behavior, with the highest value of $11.81 \mathrm{~g}^{2}$ animal $\mathrm{day}^{-1}$ for the inclusion of $1.3 \%$ urea in sheep feed. However, data from the present study indicates that levels of SRU in feed of up to $0.9 \%$ result in an increase in the NB expressed as $\% \mathrm{NI}$ and, consequently, there was a reduction in the loss of UN.

The inclusion of $0.0 \%, 0.4 \%, 0.8 \%$, and $1.2 \%$ SRU in sheep feed did not alter $(\mathrm{p}>0.05)$ the NB expressed as $\mathrm{g}$ animal day ${ }^{-1}(10.86)$ and $\mathrm{g}\left(\mathrm{kg}^{0.75}\right)^{-}$ ${ }^{1}$ (0.82) as shown in Table 3. However, the NB expressed as $\%$ NI or in relation to the NI displayed a quadratic behavior $(\mathrm{p}<0.05)$ dependent on the level of inclusion of SRU in the sheep feed (Figure 3). The maximum values of NB of $59.68 \%$ or $0.57 \mathrm{NB} /$ NI were both obtained for $0.68 \%$ SRU as calculated with the regression equation shown in Figures $3 \mathrm{~A}$ and $3 \mathrm{~B}$, respectively. Thus, it was observed that the use of SRU can provide a better synchronization of ${\mathrm{N}-\mathrm{NH}_{3}}_{3}$ release with the dietary energy pool (fermentation of organic matter), which allows a more efficient use of the nutrients of the rumen for the synthesis of microbial protein compared to diets that use common urea (SANTOS et al., 2012). Probably the lower energy expenditure for ammonia recycling in the ruminal environment could allow targeting this pool of energy and nutrients towards an increase in the microbial growth rate, consequently improving the production efficiency of the animals. 
Figure 3. Nitrogen Balance (NB) as percentage of nitrogen intake (\%NI) (A) and NB in relation to NI (B) of sheep fed diets containing different levels of slow release urea (SRU).

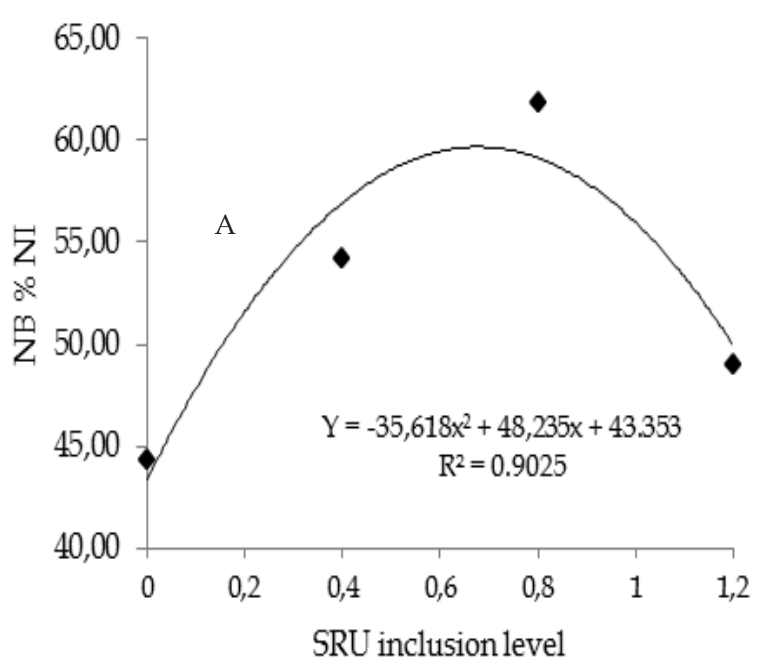

In general, a NB near zero indicates an adequate use of $\mathrm{N}$ by the ruminal microbiota, which can usually be correlated with the synchronization of the carbohydrates and CP sources of the diet (ZEOULA et al., 2006). According to Russel et al. (1992), food sources that do not allow synchronization in ruminal degradation can lead to the loss of $\mathrm{N}^{-\mathrm{NH}_{3}}$ and consequently reduce microbial synthesis with a probable reduction in food degradation. This may lead to an undesirable metabolic process such as intoxication by excess of circulating $\mathrm{N}^{-\mathrm{NH}_{3}}$, and use of energy to eliminate the excess $\mathrm{N}^{-\mathrm{NH}_{3}}$, instead of using it in the synthesis pathways of ruminal bacteria. According to Geron et al. (2016), the inclusion of up to $1.2 \%$ SRU in sheep feed does not alter the concentration of $\mathrm{N}_{-} \mathrm{NH}_{3}$ in ruminal fluid with a mean value of $20.03 \mathrm{mg} \mathrm{N}-\mathrm{NH}_{3} 100$ $\mathrm{mL}^{-1}$ ruminal fluid. Thus, the results obtained in the present study indicate that a level of SRU of $0.7 \%$ allows the best NB in sheep.

A study conducted by Geron et al. (2015a), to evaluate the NB of sheep fed diets containing 35\% of concentrate and $13 \% \mathrm{CP}$, showed that sheep had a NB of $3.54 \mathrm{~g}$ animal day ${ }^{-1}$, below that observed in the present study of $10.86 \mathrm{~g}$ animal day ${ }^{-1}$. This discrepancy is probably related to the true protein

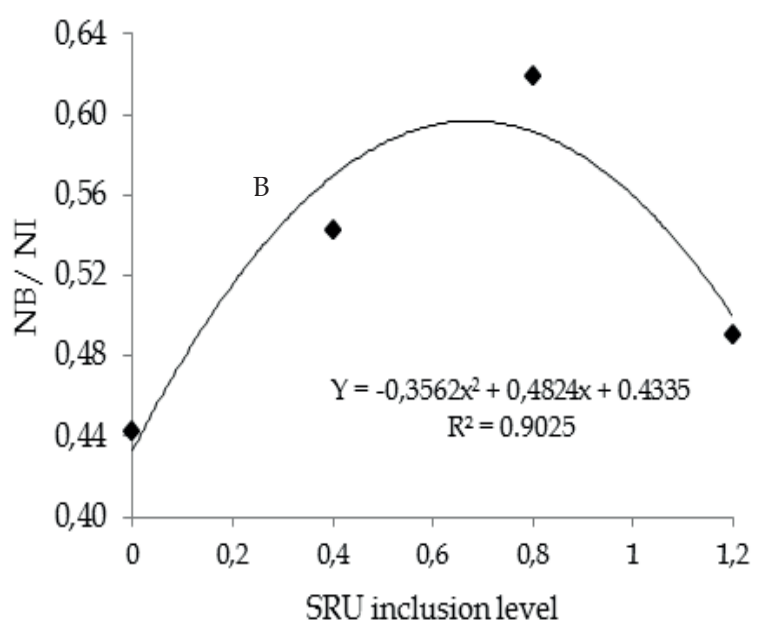

source and SRU, in addition to differences in the animal BW between the two studies. The NB in sheep with a BW of $40 \mathrm{~kg}$ and fed with a diet with a CP content of $15 \%$ containing tamarind residue was evaluated by Geron et al. (2015b). An average value of $28.70 \mathrm{~g}^{2}$ animal day ${ }^{-1}$ was obtained, which is probably related to the $\mathrm{CP}$ content of the diet and the degradation rate of the protein source.

SRU levels of $0.0 \%, 0.4 \%, 0.8 \%$, and $1.2 \%$ in sheep feed did not alter $(\mathrm{p}>0.05)$ the nitrogen absorbed (NA), which presented an average value

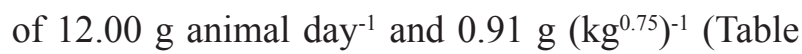
3). However, the different levels of SRU in feed influenced $(p<0.05)$ the NA expressed as $\% \mathrm{NI}$, in a quadratic manner. The maximum value observed for NA was $63.57 \%$ NI at an inclusion level of $0.66 \%$ SRU in sheep feed (Figure 4 ). This result can be explained in part by the quadratic effect, with the minimum point observed for the FN expressed as $\%$ NI (Figure 2B), which has a direct effect on the loss of $\mathrm{N}$ by the fecal route and consequently on the uptake of $\mathrm{N}$ by this route. In addition, these results are in agreement with the premise that SRU provides a slower degradation and release of $\mathrm{N}$ in the ruminal environment, which can provide an improvement in the efficiency of utilization of both $\mathrm{N}$ and energy 
sources within the rumen (ALVES et al., 2014; GONÇALVES et al., 2014). This agrees with the data obtained for the coefficient of digestibility of $\mathrm{CP}$ by Geron et al. (2016), who found that the inclusion of $0.66 \%$ SRU provided the highest estimated value of $63.55 \%$ for CP digestibility.

Figure 4. Nitrogen absorbed (NA) as percentage of nitrogen intake (\% NI) of sheep fed diets containing different levels of slow release

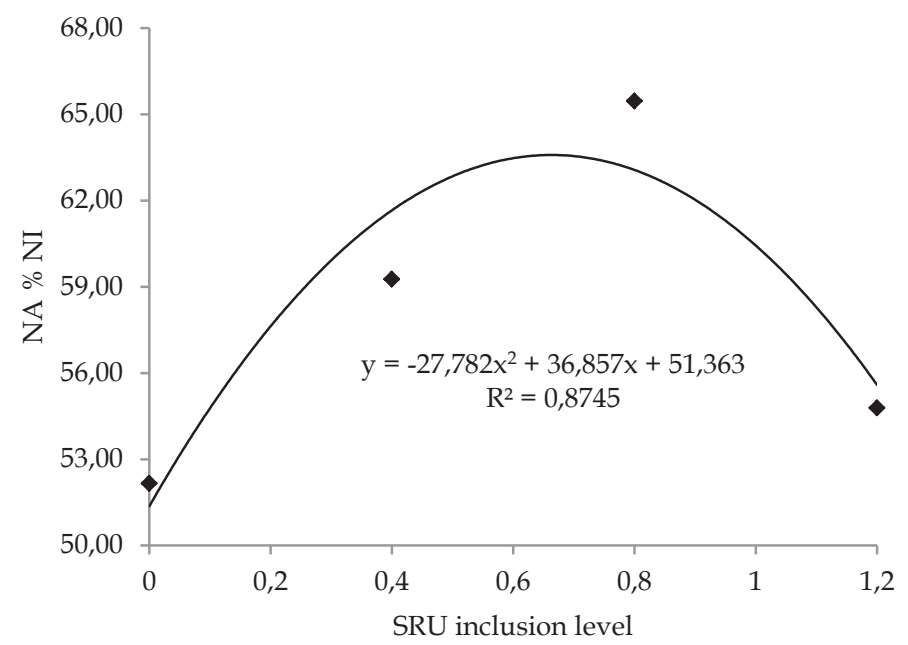

\section{Conclusions}

In conclusion, the inclusion of $0.6 \%$ to $0.8 \%$ SRU in sheep feed leads to lower losses of fecal and urinary nitrogen, and provides the best values of NB expressed as a percentage of NI.

\section{Acknowledgments}

To the students of the Bachelor's Degree in Animal Science at the State University of Mato Grosso, and to the Foundation for Research Support of the State of Mato Grosso for the scientific initiation (CI) fellowships.

\section{References}

ALVES, E. M.; MAGALHÃES, D. R.; FREITAS, M. A.; SANTOS, E. J.; PEREIRA, M. L. A.; PEDREIRA, M. S. Nitrogen metabolism and microbial synthesis in sheep fed diets containing slow release urea to replace the conventional urea. Acta Scientiarum. Animal Sciences, Maringá, v. 36, n. 1, p. 55-62, 2014.
ALVES, E. M.; PEDREIRA, M. S.; PEREIRA, M. L. A.; ALMEIDA, P. J. P.; GONSALVES NETO, J.; FREIRE, L. D. R. Farelo de vagem de algaroba associado a níveis de ureia na alimentação de ovinos: balanço de nitrogênio, N-ureico no plasma e parâmetros ruminais. Acta Scientiarum. Animal Sciences, Maringá, v. 34, n. 3, p. 287-295, 2012.

AMORIM, T. R. Digestibilidade verdadeira e exigências de proteina para mantença em tourinhos Red Norte. 2013. Dissertação (Mestrado em Nutrição e Produção de Ruminantes) - Universidade Federal de Lavras, Lavras.

ASSOCIATION OF OFFICIAL ANALYTICAL CHEMISTS - AOAC. Official methods of analysis. $15^{\text {th }}$ ed. Virginia: Arlington, 1990. 1298 p.

AZEVEDO, H. O.; BARBOSA, F. A.; GRAÇA, D. S.; PAULINO, P. V. R.; SOUZA, R. C.; LAVALL, T. J. P.; BICALHP, F. L. Ureia de liberação lenta em substituição ao farelo de soja na terminação de bovinos confinados. Pesquisa Agropecuária Brasileira, Brasília, v. 50, n. 11, p. 1079-1086, 2015.

BOURG, B. M.; TEDESCHI, L. O.; WICKERSHAM, T. A.; TRICARICO, J. M. Effects of a slow-release urea product on performance, carcass characteristics, and nitrogen balance of steers fed steam-flaked corn. Journal Animal Science, Champaign, v. 90, n. 6, p. 3914-3923, 2012. 
BRODERICK, G. A.; STEVENSON, M. J.; PATTON, R. A. Effect of dietary protein concentration and degradability on response to rumen-protected methionine in lactating dairy cows. Jounal of Dairy Science, Champaign, v. 92, n. 6, p. 2719-2728, 2009.

CARVALHO, G. G. P.; GARCIA, R.; PIRES, A. J. V.; SILVA, R. R.; PEREIRA, M. L. A.; VIANNA, P. T.; SANTOS, A. B.; PEREIRA, T. C. J. Balanço de nitrogênio, concentrações de ureia e síntese de proteína microbina em caprinos alimentados com dietas contendo cana-de-açúcar tratada com oxido de cálcio. Revista Brasileira de Zootecnia, Viçosa, MG, v. 39, n. 10, p. 2253-2261, 2010.

CASTANEDA, R. D.; BRANCO, A. F.; CONEGLIAN, S. M.; BARRETO, J. C.; GRANZOTTO, F.; TEIXEIRA, S. Substituição de ureia por cloreto de amônio em dietas de bovinos: digestibilidade, síntese de proteína microbiana, parâmetros ruminais e sanguíneos. Acta Scientiarum. Animal Sciences, Maringá, v. 31, n. 2, p. 271-277, 2009.

CLARK, J. H.; KLUSMEYER, T. H.; CAMERON, M. R. Microbial protein synthesis and flow of nitrogen fractions to the duodenum of dairy cows. Journal of Dairy Science, Savoy, v. 75, n. 5, p. 2304-2323, 1992.

DEWHURST, R. J.; DAVIES, D. R.; MERRY, R. J. Microbial protein suplly from the rumen. Animal Feed Science the Technology. London, v. 72, n. 3, p. 679-699, 2000.

FURTADO, R. N.; CARNEIRO, M. S. S.; CÂNDIDO, M. J. D.; GOMES, F. H. T.; ROGÉRIO, M. C. P.; SILVA, D.S. Balanço de nitrogênio e avaliação ruminal em ovinos machos e fêmeas alimentados com rações contendo torta de mamona sob diferentes tratamentos. Semina: Ciências Agrárias, Londrina, v. 35, n .6, p. 3237-3248, 2014.

GALLO, S. B.; PEREIRA, E. C. A.; REIS, V. A. A. Uso de duas fontes de ureia na dieta de cordeiros mestiços terminados em sistema semi-intensivo. Boletim de Indústria Animal, Nova Odessa, v. 72, n. 1, p. 8-13, 2015.

GALO, E.; EMANUELE, S. M.; SNIFFEN, C. J.; WHITE, J. H.; KNAPP, E. J. R. Effects of a polymercoated urea product on nitrogen metabolism in lactating Holstein dairy cattle. Journal of Dairy Science, Champaign, v. 86, n. 6, p. 2154-2162, 2003.

GARDINAL, R. Utilização de ureia encapsulada de liberação lenta na alimentação de novilhos Nelore. 2012. Dissertação (Mestrado em Nutrição e produção Animal) - Universidade de São Paulo. Faculdade de Medicina Veterinária e Zootecnia, Pirassununga.

GERON, L. J. V.; AGUIAR, S. C.; CARVALHO, J. T. H.; JUFFO, G. D.; SILVA, A. P.; SOUSA NETO, E.
L.; COELHO, K. S. M.; GARCIA, J.; DINIZ, L. C.; PAULA, E. J. H. Effect of slow release urea in sheep feed on intake, nutrient digestibility, and ruminal parameters. Semina. Ciências Animal, Londrina, v. 37, n. 4, p. 30413052, 2016. Suplemento 1.

GERON, L. J. V.; COSTA, F. G.; GARCIA, J.; ZANINE, A. M.; OLIVIERA, E. B.; CABRAL, L. S.; PEIRANGELI, M. A. P.; AGUIAR, S. C. Nutrients intake and digestibility in sheep fed with residue from the extraction of tamarind pulp. Semina: Ciências Agrárias, Londrina, v. 36, n. 6, p. 4401-4412, 2015b. Suplemento 2.

GERON, L. J. V.; GARCIA, J.; COSTA, F. G.; AGUIAR, S. C.; OLIVEIRA, E. B.; SILVA, M. I. L.; CABRAL, L. S.; PIERANGELI, M. A. P.; ZEOULA, L. M.; MEXIA, A. A. Ruminal parameters and nitrogen balance in sheep fed diets containing residue from the extraction of tamarind pulp. Semina: Ciências Agrárias, Londrina, v. 36 , n. 5, p. 3411-3420, 2015a.

GERON, L. J. V.; MEXIA, A. A.; CRISTO, R. L.; GARCIA, J.; CABRAL, L. S.; TRAUTAMANN, R. J.; MARTINS, O. S.; ZEOULA, L. M. Consumo, digestibilidade dos nutrientes e características ruminais de cordeiros alimentados com níveis crescentes de concentrado em ambiente tropical no Vale do Alto Guaporé - MT. Semina: Ciências Agrárias, Londrina, v. 34, n. 5, p. 2497-2510, 2013.

GONÇALVES, G. S.; PEDREIRA, M. S.; AZEVEDO, J. A. G.; REI, A. J. D.; SILVA, H. G. O.; SILVA, F. F. Replacement of soybean meal by conventional and coated urea in dairy cows: intake, digestibility, production and composition of milk. Acta Scientiarum. Animal Sciences, Maringá, v. 36, n. 1, p. 71-78, 2014.

KOZLOSKI, G. V. Bioquímica dos ruminantes. Santa Maria: UFSM, 2002. 140 p.

LIZARAZO, A. C.; MENDOZA, G. D.; KÚ, J.; MELGOZA, L. M.; CROSBY, M. Effects of slowrelease urea and molasses on ruminal metabolism of lambs fed with low-quality tropical forage. Small Ruminant Research, v. 1, n. 116, p. 28-31, 2014.

MENDES, C. Q. Fontes nitrogenadas com diferentes taxas de degradação ruminal na alimentação de ovinos. 2009. Tese (Doutorado em Ciências) - Escola Superior de Agricultura Luiz de Queiroz, Piracicaba.

MORENO, G. M. B.; SILVA SOBRINHO, A. G.; LEÃO, A. G.; LOUREIRO, C. M. B.; PEREZ, H. L.; ROSSI, R. C. Desempenho, digestibilidade e balanço de nitrogênio em cordeiros alimentados com silagem de milho ou canade-açúcar e dois níveis de concentrado. Revista Brasileira de Zootecnia, Viçosa, MG, v. 39, n. 4, p. 853-860, 2010. 
NATIONAL RESEARCH COUNCIL - NRC. Nutrient requeriments of small ruminants: sheep, goats, cervids, and new world camelids. Washington: National Academy Press, 2007. 362 p.

OWENS, F. N.; ZINN, R. Protein metabolism of ruminants. In: CHURCH, C. D. The ruminant animal: digestive physiology and nutrition. New Jersey: Waveland Press, 1993. 564 p.

PINOS-RODRIGUEZ, J. M.; PENA, L. Y.; GONZALESMUNOZ, S. S.; BARCENA, R.; SALEM, A. Effects of a slow-release coated urea product on growth performance and ruminal fermentation in beef steers. Italian Journal of Animal Science, Roma, v. 9, n. 1, p. 16-19, 2010.

PIRES,A.V.; OLIVEIRAJUNIOR, R. C.; FERNANDES, J. J. R.; SUSIN, I.; SANTOS, F. A. P.; ARAÚJO, R. C.; GOULART, R. C. D. Substituição do farelo de soja por ureia ou amireia na dieta de bovinos de corte confinados. Pesquisa Agropecuária Brasileira, Brasília, v. 39, n. 9, p. 937-942, 2004.

RUSSEL, J. B.; O'CONNOR, J. D.; FOX, D. G.; VAN SOEST, P. J.; SNIFFEN, C. J. A net carbohydrate and protein system for evaluating cattle diets: I. Ruminal fermentation. Journal of Animal Science, Champaign, v. 70, n. 4, p. 3551-3561, 1992.

SANTINO, B. T. Ureia de liberação lenta em dietas de vacas mestiças em lactação. 2013. Dissertação (Mestrado em Zootecnia) - Universidade Federal dos Vales do Jequitinhonha e Mucuri. Faculdade de Ciências Agrárias, Diamantina.

SANTOS, F. A. P.; PEDROSO, A. M. Metabolismo de proteína. In: BERCHIELLI, T. T.; PIRES, A. V.; OLIVEIRA, S. G. (Ed). Nutrição de ruminantes. Jaboticabal: FUNEP, 2011, p. 255-290.

SANTOS, F. M. S. C.; ARAÚJO, A. O.; BATISTA, A. M. V.; CARVAlHO, F. F. R.; BEM, B. S. C.; VASCONSELOS, J. L. A.; LEITE, J. S.; MORAES, A. C. Balanço de nitrogênio em ovinos alimentados com dietas à base de palma forrageira e ureia. Revista Cientifica de Produção Animal, Teresina, v. 14, n. 1, p. 89-92, 2012.

SANTOS, J. F.; DIAS JÚNIOR, G. S.; BITENCOURT, L. L.; LOPES, N. M.; SIÉCOLA JÚNIOR, S.; SILVA, J. R. M.; PEREIRA, R. A. N.; PEREIRA, M. N. Resposta de vacas leiteiras à substituição parcial de farelo de soja por ureia encapsulada. Arquivo Brasileiro de Medicina Veterinária e Zootecnia, Belo Horizonte, v. 63, n. 2, p. 423-432, 2011.

SILVA, D. J.; QUEIROZ. A. C. Análise de alimentos: métodos químicos e biológicos. 2. ed. Viçosa, MG: UFV, 2002. $178 \mathrm{p}$.

SILVEIRA, V. A. Substituição parcial de farelo de soja por ureia de liberação lenta para vacas de leite. 2013. Dissertação (Mestrado em Ciências Veterinária) Universidade Federal de Lavras, Lavras.

SNIFFEN, C. J.; O'CONNOR, J. D.; VAN SOEST, P. J.; FOX, D. G.; RUSSELL, J. B. A net carbohydrate and protein system for evaluating cattle diets: II. Carbohydrate and protein availability. Journal of Animal Science, Champaign, v. 70, n. 10, p. 3562-3577, 1992.

SOUZA, V. L. S.; ALMEIDA, R.; SILVA, D. F. F. S.; PIEKARKI, P. R. B.; JESUS, C.P. Substituição parcial de farelo de soja por ureia protegida na produção e composição de leite. Arquivo Brasileiro de Medicina e Zootecnia, Belo Horizonte, v. 62, n. 6, p. 1415-1422, 2010.

UNIVERSIDADE FEDERAL DE VIÇOSA - UFV. Sistemas de análises estatísticas e genéticas - SAEG. Versão 9.1. Viçosa, MG: UFV, 2007. 150 p.

VALADARES FILHO, S. C.; MACHADO, P. A. S.; CHIZZOTTI, M. L.; AMARAL, H. F.; MAGALHÃES, K. A.; ROCHA JÚNIOR, V. R.; CAPELLE, E. R. Tabelas brasileiras de composição de alimentos para bovinos. 3 . ed. Viçosa, MG: UFV/DZO, 2010. 502 p.

VAN SOEST, P. J.; ROBERTSON, J. B.; LEWIS, B. A. Methods for dietary fiber neutral detergent fiber, and nostarch polysaccharides in relation to animal nutrition. Journal of Dairy Science, Champaing, v. 74, n. 12, p. 3583-3597, 1991.

ZEOULA, L. M.; FERELI, F.; PRADO, I. N.; GERON, L. J. V.; CALDAS NETO, S. F.; PRADO, O. P. P.; MAEDA, E. M. Digestibilidade e balanço de nitrogênio com diferentes teores de proteína degradável no rúmen e milho como fonte de amido em ovinos. Revista Brasileira de Zootecnia, Viçosa, MG, v. 35, n. 5, p. 2179-2186, 2006. 